\title{
A CO-INTEGRATION APPROACH TO THE DETERMINANTS OF INFLATION IN NIGERIA
}

\author{
Ugwulali Ifeanyi Joseph ${ }^{\mathbf{1}}$, Adejuwon Joshua Adewale (PhD, MNIM, FCA) ${ }^{\mathbf{1}}$, \\ Ojomolade Dele Jacob (PhD, FCIB $)^{2}$ and Ogwulali Joseph. I. (PhD, FCA $)^{2}$ \\ ${ }^{1}$ Department of Management and Accounting, Lead City University, Ibadan \\ ${ }^{2}$ Department of Accounting and Finance, Caleb University, Imota.
}

Email: adejuwonwj@yahoo.co; ojomolade4real@yahoo.com

Cite this article:

Ugwulali I.J., Adejuwon J.A., Ojomolade D.J., Ogwulali J.I. (2021), A Co-integration Approach to the Determinants of Inflation in Nigeria. African Journal of Economics and Sustainable Development 4(3), 50-60. DOI: 10.52589/AJESD1NDDOCYC.

\section{Manuscript History}

Received: 18 July 2021

Accepted: 12 Aug 2021

Published: 9 Sept 2021

Copyright () 2020 The Author(s). This is an Open Access article distributed under the terms of Creative Commons AttributionNonCommercial-NoDerivatives 4.0 International (CC BY-NC-ND 4.0 ), which permits anyone to share, use, reproduce and redistribute in any medium, provided the original author and source are credited.
ABSTRACT: This study was a co-integration approach to the determinants of inflation in Nigeria. The study became necessary as a result of the rampaging effect of the increasing rate of inflation in the country particularly immediately after the fiscal crises between 1980 and 1984. The study used secondary data collected from the Central Bank of Nigeria (CBN) statistical bulletin (2012-2018). This was analysed using auto-regressive distributed lag. The findings showed that real and lagged government expenditure, exchange rate, money supply and crude oil price are the main macroeconomic factors responsible for inflation in Nigeria. Whilst exchange rate depreciation helps to reduce the level of inflation, decreases in crude oil prices increase the level of inflation. Also, growth in real government expenditure and money supply exert pressure on price levels to move up. The long run co-integration and bounds results show that there is a long run relationship between inflation and government expenditure. The lagged explanatory variables are significant at 5\% level of significance, except crude oil price. It was concluded that inflation in Nigeria is multi-dimensional and dynamic. It was therefore recommended that the government should implement policies that enhance increased production of goods and services leading to reduction in the general prices level and diversify the economic base to control the effect of inflation in Nigeria.

KEYWORDS: Inflation, Government Expenditure, Crude Oil, Co-integration, Exchange Rate. 


\section{INTRODUCTION}

According to Abraham, Helen and Moses (2015), inflation is a persistent and sustained increase in the general level of prices of goods and services in an economy over a period of time. It increases the overall price level and reduces the purchasing power of currency from performing the function of store of value. Inflation devalued the value of a country's currency compared to other nations.

Inflation leads to unfavourable development and decline in the standard of living of the average Nigerian. Inflation was noticeable in Nigeria from the period of oil discovery and windfall thereof. The fiscal crisis in Nigeria between the period of 1980 and 1984 consumed up to N17.4 billion due to budget deficit which government could finance through money creation, which is an expansionary monetary policy, as the growth rate stood at $29.9 \%$ and inflation at $20.2 \%$ due to slum in the price of crude oil (Abraham, Helen, and Moses, 2015). Exports declined due to inadequate supply of foreign exchange and as a result of the inflation, hence naira was devalued which could be noticed from dollar - Naira exchange rate, when 1981, $¥ 0.61$ was exchanged for $\$ 1$ then in $2000 \$ 102.1052,2003$ for $\$ 129.3565,2010$ for $\$ 150.2980$ and 2015 for 196.5015 for $\$ 1$ respectively, Ojomolade (2018). .

Nigeria being an import-dependent economy, import inflation as a result of a growing gap between the local demand and production, which could only be filed by import, (Abraham et al, 2015) With the Structural Adjustment Programme (SAP) introduced in 1986 and the reduction in government involvement in the economy and removal of subsidies, GDP growth rate reduced from $8.3 \%$ to $1.2 \%$ between 1990 and 1994. Inflation rate increased from $7.5 \%$ to $57.0 \%$ between 1990 and 1992 while it reduced to 18.9 percent in 2001, and subsequently it reduced from 11.80 in 2011 to 9.55 in 2015 and 16\% in 2016 (CBN 2016, African Economic outlook 2020),

Nigerian economy is under-developed despite the fact that it is richly endowed both in human and natural resources. This is due to inflation, corruption and unemployment, (Rosemary, 2013 Ojomolade, 2018). Double digit inflation discourages investment, production and increases growth in wages and consumption. It also leads to uncertainty in the value of gains and losses of borrowers and lenders, furthermore, it reduces returns on financial assets (Bashir, Nawaz, Yasin, Khursheed, Khan, and Junaid, 2011. Oni, 2018). High inflation rate erodes the gains from growth and leaves the poor worse off, causing an upward adjustment in government budgets as budgetary imbalances become entrenched causing resurgence of macroeconomic instability.

Importations became expensive as currency was devalued leading to fall in agricultural products. In 1995, inflation rate rose to $72.8 \%$ as a result of the high level of financial institutions lending to individuals and firms, (Rosemary, 2013) as determinants of inflation are not properly controlled, Nigeria was vulnerable to unpredictability inflation rate, disturbing the consumption, investment and production behaviour (Inyiama,2013). According to Dania, (2015) there are many determinants of inflation which include exchange rate, money supply, bank rate, government debts, government expenditures and others.

Therefore, the objective of this study is to identify the determinants of inflation in Nigeria and establish the relationship between government expenditure and inflation, and also to examine the influence of exchange rate on inflation in Nigeria. 


\section{CONCEPTUAL REVIEW}

Inflation is one of the most frequently used terms in economic discussions, yet the concept is variously misconstrued. There are various schools of thought on inflation, but there is a consensus among economists that inflation is a continuous rise in the prices, simply put, inflation describes an economic situation where there is a general rise in the prices of goods and services continuously. It could be defined as a continuing rise in prices as measured by an index such as the consumer price index (CPI) or by the implicit price deflator for Gross National Product (GNP). Inflation is frequently described as a state where "too much money is chasing fewer goods". Inflation allows the currency to lose purchasing power, (Chude and Chude 2015).

\section{Types of Inflation:}

Creeping inflation: This is a gradual rise in the prices of goods and services over a period. It is useful for economic growth because it stimulates investments. Hyperinflation is a situation whereby money loses its purchasing power as a store of value as the inflation rate is no longer measurable and absolutely uncontrollable. Price or Wage inflation simply means an increase in prices or wages demanded by workers or employees reflecting the increases in the general price level, Chude (2015). Running inflation this inflation rises rapidly as to when a horse is running at a rate of about 10 to 20 percent per annum and adversely affects the middle class and the poor. Adequate monetary and fiscal measures are needed to control it.

Sources of Inflation: The situations that called for inflation are: Demand-pull inflation where too much money is chasing few goods. Based on this theory, excess aggregate demand over aggregate supply will cause inflationary rise in prices. (Jhingan,2015) Cost push inflation is caused by increase in prices of factors of production, which may be an increase in cost of land, labour or capital (raw materials). The Keynesian theory on demand pull inflation says that as long as unemployed resources exist in the economy, an increase in investment expenditure will bring about an increase in employment, output and income. The bottleneck appears once full employment is reached, any more increase in expenditure will cause excess demand because output isn't rising, thereby causing inflation.

The higher the aggregate demand, the higher the national output, the national output is equal to the national income and, as we know, this is also the gross domestic product.

$\mathrm{GDP}=\mathrm{C}+\mathrm{I}+\mathrm{G}+(\mathrm{X}-\mathrm{M})$

Where $\mathrm{C}$ is household consumption, $\mathrm{I}=$ investment, $\mathrm{G}=$ government expenditure,

$\mathrm{X}=$ total exports, and $\mathrm{M}=$ total imports

Therefore, the determinants of aggregate demand are household consumption, investment, government expenditure and net exports.

The theory of modern quantity led by Friedman states that "inflation is always and everywhere a monetary phenomenon". The higher the nominal money supply rate grows, the higher the inflation rate. When the supply of money increases, more money is spent in relation to the supply of goods and services that is available. This pushes the price up. Theory of modern quantity doesn't assume full employment as a usual condition and also doesn't assume a stable 
velocity of money. Still, they believe inflation is caused by excessive increase in the supply of money.

\section{Explanatory Variables and Inflation}

Money supply and inflation: Inflation has been broadly described as an economic situation where increase in money supply grows faster than the production of new goods and services in the same economy (Ojomolade and Oni, 2018). Inflation is a sustained rise in the general price level of goods and services brought about by high rate of expansion in the aggregate money supply in the economy without any corresponding increase in their productivity, giving rise to an increase in the aggregate demand for goods and services which cannot be met at the current prices, (Sola and peter, 2013).

Money supply in Nigeria: According to Owolabi and Adegbite (2014), money supply is the amount of money available within a specific economy for the purchasing of goods or services (e.g. notes, coins and demand deposits). The stock of money can be measured at any given time in an economy (Owolabi \& Adegbite, 2014). Monetary policy is an important instrument for controlling change in money supply as it influences the interest rate and total liquidity in the economy and inflation rate (Owolabi \& Adegbite, 2014).

Exchange rate and inflation: Exchange rate is one of the determinants of inflation rate as it is the value of the domestic currency in terms of foreign currency value. According to Eze and Okpala (2014), exchange rate policy in Nigeria has moved from a fixed exchange rate regime in 1960, to a pegged regime between 1970s and mid 1980s and finally to variant of the floating regimes from 1986 with the introduction of the Structural Adjustment Programme to achieve a realistic exchange rate for the naira and to reduce inflation, among other objectives.

Crude oil price and inflation: Nigeria budget is majorly based on oil receipts. In 1981, the crude prices averaged $\$ 35.75$ per barrel as against $\$ 14.95$ per barrel in 1978 leading towards economic recession and enlarged foreign debt profile of about N8.8bn in 1982 as against $\mathrm{N} 1.25 \mathrm{bn}$ in 1978 , and oil revenues of N12.35bn in 1980 sunk to N7.81bn in 1982 . These situations culminated in lack of confidence in the Nigerian economic performance and massive capital flight, estimated at US\$14bn between 1979 and 1983. (Johnson, Ofunrein, Akeni, and Agbaje, 2017)

In 2016 the Nigeria economy slid into recession again due to vulnerability from oil prices fluctuation and endemic corruption, as well as poor visioning that subverted the fundamentals to uplift the living standards of the citizens. (Johnson et al, 2017).

Government expenditure and inflation: Government expenditure (GE) refers to money spent by the government in providing social amenities for her citizenry and protecting its territorial integrity. Inflation is the sustained general level of price of goods and services in the economy. 


\section{THEORETICAL REVIEW}

The relevant theories reviewed in the course of this study include the following:

The Quantity Theory of Money: According to (Chude, 2015. Ojomolade and Oni, 2018), this theory is reflected in fisher's equation of exchange which is MV=PQ. Where $M$ is money in circulation, $\mathrm{V}$ is velocity of money, $\mathrm{P}$ is price level, and $\mathrm{Q}$ is quantity of goods and services. $\mathrm{V}$ and $\mathrm{P}$ being held constant, it implies that a change in the quantity of money in an economy causes changes in the level of general prices. This Cambridge cash balance equation aligns with the new application of mathematics in economic analysis or synthesis. The monetary economists focus on the fact that any alteration in the money stock in an economy only has an effect on the monetary side of the economy or price level, having the real sector of the economy completely set aside. This shows that the output of goods and services are not affected by changes in the money stock, but only by their prices for which they are traded. (Animu, Anono, 2012).

Monetary Theory of Inflation: Monetarism as stipulated by Milton Friedman (1912- 2006) holds that "only money matters", and as a result, monetary policy is a more reasonable macroeconomic tool than fiscal policy in stabilization of the economy. Monetary economists view the money supply as the "dominant, though not exclusive" determinant of long run and short run prices and the level of output in the short run. The role of money is what the monetarists emphasize. (Jalil, 2011). Monetarists advocate that "inflation is always and everywhere ", therefore when inflation rate contained in money supply is higher than interest rate contained in the real output of commodities, it results in a rise in the price level. (Chude 2015).

Demand Pull Theory: In the Keynesian school of thought, increase in aggregate demand is emphasized as the main cause of demand-pull inflation. The aggregate demand includes consumption, investment and government expenditure. The wider the extent of the gap between aggregate demand and aggregate supply, the more rapidly inflation grows. According to the Keynesian school of thought, factors of production and several constants possibly cause increase in prices even before attaining full employment. The demand-pull paradigm is of the view that inflation exists when aggregate demand for goods and services exceed aggregate supply for goods and services, such that the excess aggregate demand cannot be satisfied by running down the existing stocks, diverting supplies from the export market to the domestic market, increasing imports or postponed demand. (Abraham, Helen, \& Moses, 2015)

\section{EMPIRICAL REVIEW}

Ogbole and Momodu (2015) carried out a study on government expenditure and inflation. The study investigates the nature and extent of causal relationship between government expenditure and inflation rate for 42-year period (1970-2011). Jonathan and Ezie (2015), examined empirically the causal relationship between public expenditure growth and inflation in Nigeria from 1981 to 2012.He employed econometric techniques; Augmented Dickey-Fuller (ADF) for Unit Root test, Johansen Co-integration test and the Granger Causality test and test revealed a long run relationship among the variables. It was evidenced that there is no statistically discernible relationship between government expenditure growth and inflation during the period reviewed. 
David (2013) attempted to move beyond the outcomes of the classical causality test and allow an asymmetry causal relationship between government spending and inflation rate for policy purposes in Nigeria. The idea of asymmetry causality is that positive and negative changes may have different causal impacts. The result shows a uni-directional causality running from low or contractionary government spending to high inflation in Nigeria. The implications of this is that the government should ensure a stable and steady level of spending that will keep the economy on the steady state path. Secondly, the government should accumulate savings to eliminate any shock to its spending level.

Gap to fill: This study analysed the major determinants of inflation in Nigeria in the context of an Auto-regressive parsimonious model to account for the time varying property exhibited by the variables employed which many authors have ignored in the course of their research efforts.

\section{Methodology}

The data used are secondary collected from the Central Bank of Nigeria statistical bulletin and analysed using auto-regressive distributed lag.

Model Specification

$\operatorname{Inf}_{\mathrm{t}}=f($ gve, exrmys, cdp)

The linear relationship is expressed as;

$\operatorname{Inf}_{t}=\beta_{0}+\beta_{1}$ gve $_{t}+\beta_{2} e x r_{t}+\beta_{3 m y s_{t}}+\beta_{4 c d p_{t}+U_{t}}$

Where: Inf $=$ inflation, $\beta o=$ Intercept $, \quad \beta_{1}, \beta_{2}, \beta_{3}, \beta_{4}, \beta_{5}=$ estimation coefficient

gve $=$ government expenditure, exr $=$ exchange rate, mys $=$ money supply

cdp $=$ crude oil price, $\mathrm{u}=$ error term

\section{RESULTS AND DISCUSSION OF FINDINGS}

Table 1: Descriptive Statistics

\begin{tabular}{|l|l|l|l|l|l|}
\hline & INF & GVe & EXR & MYS & CDP \\
\hline Mean & 19.34054 & 1371715. & 75.06543 & 4059.814 & 43.20757 \\
\hline Median & 12.20000 & 487113.4 & 21.89000 & 488.1458 & 30.57000 \\
\hline Maximum & 72.80000 & 4813378. & 310.0000 & 21607.68 & 117.1000 \\
\hline Minimum & 5.400000 & 9636.500 & 0.550000 & 14.38900 & 11.21000 \\
\hline Std. Dev. & 17.51557 & 1662158. & 80.85932 & 6311.861 & 31.15400 \\
\hline Skewness & 1.706246 & 0.958371 & 0.923555 & 1.491297 & 1.205734 \\
\hline Kurtosis & 4.675368 & 2.360901 & 3.195973 & 3.867535 & 3.125877 \\
\hline
\end{tabular}

Source: Author's Computation 2020 
It can be inferred from the descriptive statistics that the government expenditure has the largest value of mean and standard deviation of 1371715 and 1662158 respectively, while inflation rate has the least mean and standard deviation values of 19.34054 and 17.51557 respectively. All variables are positively skewed and the inflation rate has the highest peak value (kurtosis) of 4.675368. Government expenditure has the highest maximum and minimum value of 4813378 and 9636.500 . While inflation has the lowest maximum value of 72.8 , and exchange rate has the lowest minimum value of 0.55 .

\section{Unit Root Test (Augmented Dickey-Fuller and Phillip Perrons)}

This study presents the results of Augmented Dickey-Fuller and Phillip Perrons unit roots statistical test. The variables considered were stationary at first difference, which implies that they are integrated at order one at the 5\% level of significance, but after the first difference at $5 \%$ level of significance, all the variables became stationary indicating the absence of a spurious and misleading interpretation of the regression line.

Table 2: ARDL Bounds Test

Test Statistic Value K

F-statistic $\quad 6.560086 \quad 2$

Critical Value Bounds

Significance $\quad$ I0 Bound I1 Bound

$\begin{array}{lll}10 \% & 3.17 & 4.14 \\ 5 \% & 3.79 & 4.85\end{array}$

Long Run Coefficients

\begin{tabular}{crrrr}
\hline Variable & Coefficient & Std. Error & t-Statistic & Prob. \\
& & & & \\
\hline GENRL & 17.110654 & 8.414520 & -2.033468 & 0.0509 \\
EXR & 0.027931 & 0.067495 & 0.413829 & 0.6819 \\
C & 77.888838 & 26.225768 & 2.969935 & 0.0058
\end{tabular}




\section{Long Run Co-integration and Bounds Test}

Long run test, the coefficient of the constant is negative and its probability is 0.0289 which is below 5\% level of significance. The probability of log government expenditure, log money supply and exchange rate are below the 5\% level of significance, which shows that each of the explanatory variables have a long run relationship with inflation in Nigeria. While the probability of log crude oil price is above the $5 \%$ level of significance, which means that it does not have an effect on inflation in the long run.

In the bounds test, the value of the f-statistics, 29.27 is greater than the I(1) value, 3.49, at 5\% level of significance. This shows that there is cointegration among the variables.

\section{Serial Correlation}

Table 3 Breusch-Godfrey Serial Correlation LM Test:

$\begin{array}{llll}\text { F-statistic } & 0.407153 & \text { Prob. F(2,28) } & 0.6694 \\ \text { Obs*R-squared } & 0.989117 & \text { Prob. Chi-Square(2) } & 0.6098\end{array}$

\section{Table 4: Normality Test}

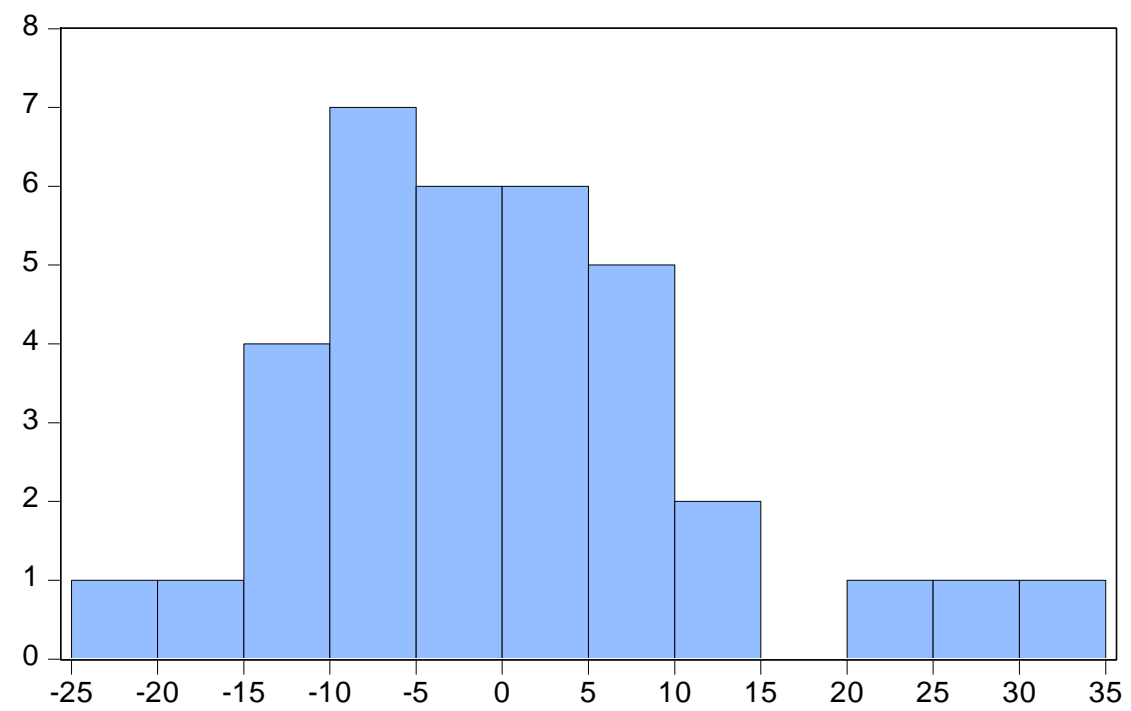

Series: Residuals

Sample 19822016

Observations 35

Mean

Median

$-1.518634$

Maximum $\quad 33.95094$

Minimum $\quad-22.42715$

Std. Dev. $\quad 12.26845$

Skewness $\quad 0.806796$

Kurtosis $\quad 3.792447$

Jarque-Bera 4.712825

Probability $\quad 0.094760$ 


\section{Heteroskedasticity}

Table 5: Heteroskedasticity Test: Breusch-Pagan-Godfrey

$\begin{array}{llll}\text { F-statistic } & 2.656708 & \text { Prob. F(4,30) } & 0.0521 \\ \text { Obs*R-squared } & 9.155012 & \text { Prob. Chi-Square(4) } & 0.0573 \\ \text { Scaled explained SS } & 9.391182 & \text { Prob. Chi-Square(4) } & 0.0520\end{array}$

From the outcome of a number of diagnostic tests of normality, serial correlation, and heteroskedasticity performed on the autoregressive distributed lag model to decide whether the model was well specified. The histogram normality reveals that the residual is normally distributed, evident from the probability value 0.094 of the Jarque-Bera statistics that is greater than $5 \%$ level of significance, to test for serial correlation the Breusch- Godfrey LM test is employed and it thus suggests that there is no serial correlation in the residual of the model. Since the null hypothesis of no serial correlation is not rejected because the probability value 0.407 of the $\mathrm{F}$ statistics is greater than $5 \%$ level of significance. Heteroskedasticity problem was absent since the null hypothesis of no heteroscedasticity was not rejected because the probability value was 0.06 .

\section{Cosum Test}

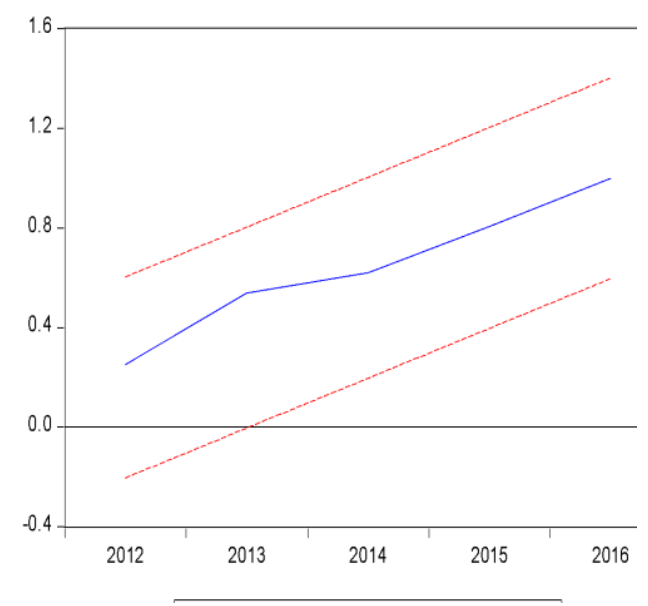

\section{Cosum of Square Test}

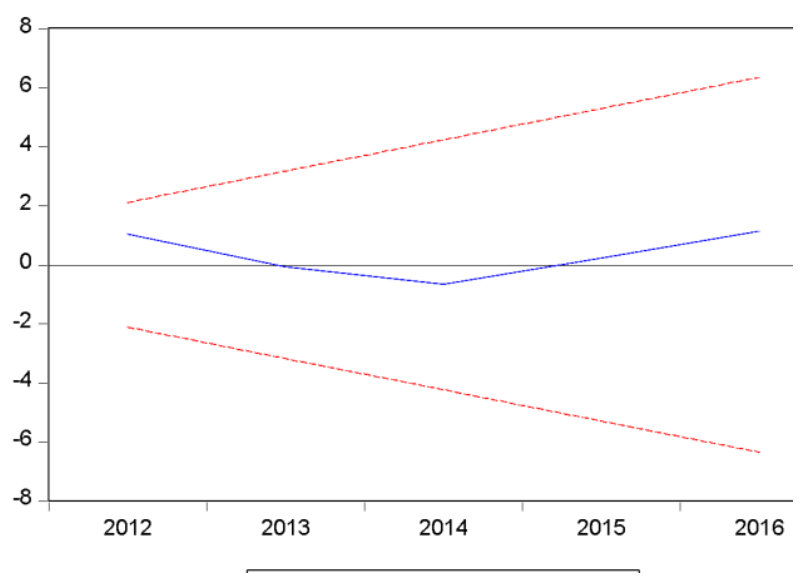

Both the CUSUM and the CUSUM of squares tests show the variables are stable, and this is because they fall within the stability range. 


\section{CONCLUSION AND RECOMMENDATIONS}

Based on the empirical findings from this study, it is concluded that real and lagged government expenditure, exchange rate, money supply, and crude oil price are the main macroeconomic factors responsible for inflation in Nigeria. Whilst exchange rate depreciation helps reduce the level of inflation, decreases in crude oil prices increase the level of inflation, growth in real government expenditure and money supply exert pressure on price levels to move up. The long run co-integration and bounds test reveal that there is a long run relationship between inflation and government expenditure the lagged explanatory variables are significant at 5\% level of significance. The determinants of inflation in Nigeria are multi-dimensional and dynamic. Therefore, the government should implement policies that enhance increased production of goods and services leading to reduction in the general price level and diversify the economic base to control the effect of inflation on Nigeria economic growth.

\section{REFERENCE}

Abraham A. Helen,A.A. and Moses,G.D (2015) Analysis of the Main Determinants of Inflation in Nigeria. Research Journal of Finance and Accounting. Vol.6 issue 2

African Economic Outlook 2020. Developing African Workforce for the Future. African Development Bank Group

Aminu, U and Anono,A. Zuburu 2012 Effect of Inflation on the Growth of Development of the Nigerian Economy.AN Empirical Analysis. International Journal of Business and Social Sciences Vol3. No10

Bashir, N. Khursheed,I.U and Muhammad ,J.O.(2011) Determinant of Inflation in Pakistan.An Econometric Analysis Using Johansen Cointegration Approach Journal of Business and Management Research. Vol.1. no5

Chude, D.I and Chude,,N.P (2015) Impact of Inflation and Economic Growth in Nigeria. Central Bank of Nigeria 2016. Education Economics International Journal of Business Management Review. Vol.1,no 4

Dania, E. N. 2015.Determinants of inflation in Nigeria (1970 - 2010). Institute of Continuing Education (ICE). Benin, Edo State, Nigeria

David, O.O. (2013) Government Spending and Inflation in Nigeria. Asymmetry Causality Test. International Journal of Humanity and Management Sciences.Vol.1.1

Eze. T. C., Okpala, C. S. 2014. Quantitative Analysis of the Impact of Exchange Rate Policies on Nigeria's Economic Growth: a Test of Stability of Parameter Estimates. International Journal of Humanities and Social Science Vol. 4, No. 7; May 2014

Inyiama, O.I (2013) Does Inflation Weaken Economic Growth? Evidence from Nigeria. European Journal of Accounting, Auditing and Finance Research.Vol.1 no 4

Jalil T. 2011. Macroeconomic Theories of Inflation. International Conference on Economics and Finance Research IPEDR vol.4

Jhingan,M.L. 2015 Principles of economics $4^{\text {th }}$ revised and enlarged edition. Vrinda publications ( $p$ ) ltd.

Johnson. O. Ezie, and Torbira, M. T.2015. Public Expenditure Growth and Inflation in Nigeria: The Causality Approach. International Journal of Economics and Management Studies (SSRG-IJEMS) - volume2 issue 1

Johnson. Ofunrein. Akeni. and Agbaje, K. 2017. The Nigerian Economy: A Short History of How Oil Price and Production Swings Determine The Fate of a Nation. 
Ogbole O. F, Momodu A. A. 2015. Government Expenditure and Inflation Rate in Nigeria: An Empirical Analysis of Pairwise Causal Relationship. Research Journal of Finance and Accounting vol 6,no15

Ojomolade,D.J. and Oni, O. (2018) Impact of Inflation on Economic Growth in Nigeria. Caleb Journal of Social and Management Sciences Vol. 4 no2

Owolabi, A.U and Adegbite ,T. Adejare. (2014) Foreign Exchange Regimes and Economic Growth in Nigeria .Research and Journal of Finance and Accounting. Vol.5.no 8

Rosemary E. 2015. Impact of Inflation on Economic Growth: Case Study of Nigeria (19702013). Institute of Graduate Studies and Research.

Rosemary Idalu Emike .2015. Impact of Inflation on Economic Growth: Case Study of Nigeria (1970-2013) Institute of Graduate Studies and Research

Sola,O and Peter,A (2013) Modern Economy. http:/www.scirp.org/journal/me.2013.43018 online March 2013 